\title{
PENGEMBANGAN PERANGKAT PEMBELAJARAN DIGITIAL BERBASIS PROBLEM BASED LEARNING UNTUK MENINGKATKAN KEMAMPUAN BERPIKIR KRITIS SISWA TEMA PERAN DAN FUNGSI SUMBER DAYA ALAM
}

\author{
Gita Nurmareta Sari \\ Program Studi Pendidikan IPS, Pascasarjana, Universitas Negeri Surabaya \\ Email : gitazakki@gmail.com
}

\begin{abstract}
Abstrak
Penelitian ini bertujuan (1) menghasilkan perangkat pembelajaran digital berbasis Problem Based Learning untuk meningkatkan kemampuan berpikir kritis siswa pada tema peran dan fungsi sumber daya alam; dan (2) untuk mendeskripsikan keefektifan perangkat pembelajaran digital yang dikembangkan untuk meningkatkan kemampuan berpikir kritis siswa pada tema peran dan fungsi sumber daya alam.

Penelitian ini adalah penelitian $R \& D$ atau penelitian pengembangan. Metode penelitian ini digunakan untuk menghasilkan produk tertentu dan menguji keefektifan produk tersebut. Desain penelitian ini menggunakan 4D Thiagarajan yang telah dimodifikasi. Fokus penelitian adalah pengembangan perangkat pembelajaran yang menghasilkan produk berupa silabus, RPP, BAS, LKS, instrumen penilaian pengetahuan dan keterampilan berpikir kritis, dan media.

Analisis data pada penelitian ini menggunakan teknik analisis validitas perangkat pembelajaran, dengan menggunakan rumus percentage of agreement. Keefektifan perangkat pembelajaran yang dihasilkan dari penelitian ini dianalisis dengan menggunakan analisis deskriptif kuantitatif. Hasil penelitian menunjukkan perangkat pembelajaran yang dikembangkan yang terdiri dari silabus, RPP, BAS, LKS, Tes pengetahuan dan keterampilan berpikir kritis, dan media memiliki kategori sangat valid dan layak digunakan dalam pembelajaran. Berkaitan dengan keefektifan seluruh perangkat pembelajaran yang telah divalidasi dan diujicobakan kepada siswa kelas VIII SMP N 10 Mataram, dari data diperoleh nilai keterlaksanaan RPP yaitu sebesar 96,3\% dengan kategori terlaksana sangat baik. Perolehan penilaian hasil belajar siswa dari aspek pengetahuan dilihat dari nilai pre-test dan pst-test yang kemudian diolah dengan menggunakan rumus gain ternormalisasi sebesar 0,68 dengan kategori sedang. ketuntasan klasikal sebesar 91\%. sedangkan untuk hasil peningkatan kemampuan berpikir kritis terdapat kenaikan nilai $\mathrm{N}$-gain sebesar 0,62 dengan kategori sedang. Ketuntasan klasikal sebesar $76 \%$.
\end{abstract}

Kata-kata kunci : pengembangan perangkat digital, pembelajaran Problem Based Learning, kemampuan berpikir kritis

\begin{abstract}
This research has the goal to 1) produce a learning digital device social studies integrated with problem based learning to improve student's critical thinking skill on the theme of the role and function of natural resourches, and 2) to describe the effectiveness of Problem Based Learning method's with digital learning tools developed to enhanced student's critical thinking skill on the theme of the role and function of natural resourches.

This research is R \& D or research and development. This study design using 4D Thiagarajan models has been modified. The focus of this research is the development of social learning device that produces result in the form of product research syllabi, lesson plan, student books, worksheet, assessment instrument of knowledge and critical thinking skill and media macromedia flash.

Analysis of the data in this study using analytical techniques validity learning device using the formula percentage of agreement. The effectiveness of the learning device resulting from this study were analyzed using quantitatives descriptive analysis. The result showed that developed learning tools that include syllabi, lesson plans, student books, worksheet, test instrument of the knowledge and critical thinking skill and the media have very valid and worthy of categories used in the study. In connection with the effectiveness of the entire learning tools that have been validated and tested in class VIII SMPN 10 Mataram, from the data obtained RPP values realized in the amount of $96,3 \%$ to category very well done. Acquisition of assessment of student learning outcome of knowledge visible aspect of the pre test and post testwere then processed using the formula normalized gain of $0,68 \%$ in the medium category. Classical completeness of $91 \%$. As for the
\end{abstract}


resulting increase in the ability of critical thinking skill are $\mathrm{N}$-gain value increase of $0,62 \%$ in the medium category with classical completeness $76 \%$.

Key words: digital software development, problem based learning models, critical thinking ability.

\section{PENDAHULUAN}

Pendidikan merupakan bagian yang sangat penting untuk mengembangkan kemampuan dan watak suatu bangsa berdasarkan tujuan dan cita-cita bangsa. Menurut Sagala (2006), melalui pendidikan keterampilan intelektual, sosial dan personal dapat dikembangkan. Pendidikan adalah usaha sadar terencana untuk mewujudkan suasana belajar dan proses pembelajaran agar peserta didik secara aktif mengembangkan potensi dirinya untuk memiliki kekuatan spiritual keagamaan, pengendalian diri, kepribadian, kecerdasan, akhlak mulia, serta keterampilan yang diperlukan untuk dirinya dan masyarakat.

Pendidikan nasional berfungsi
mengembangkan kemampuan dan membentuk watak serta peradaban bangsa yang bermartabat dalam mencerdaskan kehidupan bangsa, bertujuan untuk mengembangkan potensi siswa agar menjadi manusia yang beriman dan bertakwa kepada Tuhan Yang Maha Esa, berakhlak mulia, sehat, berilmu, cakap, kreatif, mandiri dan menjadi warga negara yang demokratis serta bertanggung jawab (UU No. 20 tahun 2003 pasal 3 tentang sistem pendidikan nasional).

Pencapaian tujuan pendidikan tersebut, seharusnya dilakukan oleh pemangku pendidikan dari pemerintah hingga tenaga pendidik. Upaya pemerintah untuk mencapai tujuan pendidikan adalah dengan membuat kurikulum sesuai dengan perkembangan ilmu pengetahuan dan teknologi yang berkembang dengan pesat. Dengan adanya evaluasi terhadap kurikulum lama dan disertai dengan mendesain kurikulum baru yang proses belajarnya syarat dengan model-model pembelajaran saintifik, diharapkan pendidikan di Indonesia mampu menjawab tantangan di era global.

Pesatnya perkembangan teknologi, komunikasi dan komputer telah mengantarkan masyarakat memasuki era globalisasi. Setiap individu di era global diharapkan mampu mengembangkan kapasitasnya secara maksimal, kreatif dan mengadaptasikan diri kedalam situasi global yang sangat bervariasi dan cepat berubah. Setiap individu dituntut untuk mengembangkan daya berpikir kreatif dan kepribadian yang kompleks. Untuk mengembangkan kemampuan tersebut, maka keterampilan yang harus dimiliki oleh individu adalah keterampilan intelektual, sosial dan personal (Suprijono, 2009).

Dalam dunia pendidikan, lahirnya generasi e-learning juga telah membawa perubahan dalam proses belajar mengajar. Pendidikan digital atau e-learning merupakan sebuah konsep pendidikan yang menggunakan teknologi internet dan komputer sebagai alat bantu. Dalam $e$ learning, kegiatan belajar mengajar dapat dilakukan dengan alat bantu berbasis web dan dirancang untuk kegiatan belajar jarak jauh. Proses belajar mengajar yang berkembang dewasa ini menggunakan berbagai media digital interaktif. Penggunaan media digital dalam pembelajaran akan membuat suasana belajar lebih hidup dan aktif. Hal ini karena siswa semakin tertarik untuk mengikuti kegiatan pembelajaran dengan melihat tampilan.

Pemberlakuan kurikulum 2013, menghendaki implementasi dalam pembelajaran dengan menggunakan pendekatan saintifik. Pendekatan ini dirancang agar peserta didik mengonstruk. Berdasarkan uraian tersebut, implementasi pembelajaran IPS (Ilmu Pengetahuan Sosial) harusnya dapat mendekatkan siswa dengan dunia nyata dan mengaitkannya dengan pengetahuan awal yang dimiliki dari kegiatan maupun peristiwa yang berada pada lingkungan terdekat mereka. Problem Based Learning merupakan sebuah model pembelajaran yang menyajikan masalah kontekstual sehingga merangsang peserta didik untuk belajar dan bekerja secara berkelompok untuk memecahkan masalah dunia nyata sehingga akan terjadi pembelajaran yang bermakna. Dengan siswa dibiasakan untuk menyelesaikan masalah, maka siswa dibiasakan pula menghadapi tantangan dalam kehidupan.

Pemilihan Problem Based Learning dalam pembelajaran IPS sangat bermanfaat karena dapat mendorong peserta didik untuk belajar memecahkan masalah. Dengan menerapkan dan mengintegrasikan pengetahuan dan keterampilan yang dimilikinya serta mengaplikasikannya dalam konteks yang relevan, serta dapat meningkatkan kemampuan berpikir kritis, 
menumbuhkan inisiatif peserta didik dalam bekerja, motivasi internal untuk belajar dan dapat mengembangkan hubungan interpersonal dalam bekerja kelompok. Dengan meningkatkan kemampuan berfikir kritis inilah, siswa dapat meningkatkan keberhasilannya dalam menghadapi berbagai masalah di dunia nyata. Menurut Schafersman (1991) seseorang yang berpikir kritis dapat mengajukan pertanyaan dengan tepat, mengumpulkan informasi yang relevan, efisien, dan kreatif, beralasan logis dan membuat kesimpulan yang reliabel dan percaya tentang dunia yang memungkinkan seseorang untuk hidup dan bertindak dengan sukses didalamnya.

Penelitian tentang hubungan Problem Based Learning, berpikir kritis dan pembelajaran digital juga telah dilakukan oleh beberapa peneliti. Katerina (2016), dalam penelitiannya menyatakan bahwa $e$ learning dapat mengakuisisi keahlian dan transformasi pendidikan di era digital. Dalam perkembangannya, siswa lebih tertarik dengan pembelajaran berkonsep $e$ learning dimana belajar dapat dilakukan dimanapun, dalam situasi apapun. Perkembangan e-learning yang telah terjadi sekarang ini meningkat secara signifikan. Hal ini terbukti dari lebih dari 38 juta artikel telah diterbitkan dalam berbagai bahasa oleh Wikipedia (https://id.wikipedia.org/wiki/Wikipedia, diakses 13 Januari 2017, pukul 8.15). Perkembangan dunia digital juga telah menarik minat swasta dan para guru untuk mengembangkan konten-konten pendidikan yang interaktif.

Senada dengan penelitian tersebut, Amalia Rahmah (2015) dalam penelitiannya membangun model literasi digital yang dikaji dengan rancangan ilmu pengetahuan teoritis. Dalam penelitian ini, dikaji relevansi antara pesatnya perkembangan teknologi internet dan komputer di Indonesia dengan kondisi melek digital masyarakatnya di berbagai daerah. Untuk mengimbangi pesatnya perkembangan ICT, maka diperlukan pengawasan dari orang tua sehingga internet sehat dapat terlaksana dan tujuan dari pendidikan literasi digital dapat tercapai dengan baik.

Mahboobeh (2014) juga melakukan penelitian tentang berpikir kritis yang merupakan salah satu tujuan utama dari pendidikan. Untuk mengembangkan kemampuan berpikir kritis, maka siswa dilatih untuk mampu mengevaluasi bukti, membedakan benar dan salah, mengolah informasi yang didapat dan menarik kesimpulan. Ada dua pendekatan yang dapat digunakan dalam mengembangkan kemampuan berpikir kritis siswa, yaitu pendekatan pendidikan keterampilan umum dan pendekatan yang mengadaptasi kemampuan guru untuk mengembangkan kemampuan berpikir kritis siswa dengan mengembangkan model dan bahan pembelajaran. Dalam penelitian ini, $e$ learning digunakan untuk menumbuhkan dan mengembangkan kemampuan berpikir kritis siswa karena masalah-masalah yang di sajikan dalam pembelajaran lebih faktual dan nyata.

Data yang dimiliki oleh guru IPS di SMP Negeri 10 Mataram menunjukan ketuntasan belajar siswa pada materi peran dan fungsi sumber daya alam masih rendah dibandingkan dengan materi lainnya. Data guru menunjukan, pada semester genap tahun ajaran 2015/2016, nilai ketuntasan siswa dalam ulangan harian masih kurang dari $60 \%$. Hasil wawancara dari guru IPS SMP Negeri 10 Mataram, diketahui bahwa selama pembelajaran yang melibatkan berpikir kritis siswa kurang berjalan secara maksimal. Salah satu penyebabnya adalah keterbatasan waktu guru dalam mengembangkan perangkat pembelajaran yang dapat melatih kemampuan berpikir kritis siswa. Guru belum maksimal dalam melaksanakan pembelajaran konstruktivistik, sehingga siswa kurang terlibat aktif dalam proses pembelajaran. Guru beranggapan bahwa keberhasilan siswa dalam kegiatan belajar ditentukan oleh hasil belajar pada aspek kognitif saja, sedangkan aspek yang lain cenderung diabaikan. Padahal, proses pembelajaran yang berorientasi pada guru (teacher oriented) akan menyebabkan siswa menjadi cepat bosan dalam mengikuti proses pembelajaran, sehingga proses pembelajaran menjadi tidak efektif dan efisien (Prastowo, 2014: 13-14).

Salah satu pengembangan perangkat yang digunakan dalam penggunaan bahan ajar adalah bahan ajar berbasis digital. Bahan ajar digital berbasis macromedia flash diyakini dapat meningkatkan minat siswa dalam pembelajaran IPS. Bahan ajar berbasis macromedia flash berisi beberapa elemen seperti suara, gambar, teks, animasi dan video, sehingga siswa diharapkan dapat lebih memahami materi peran dan fungsi sumber daya alam yang disajikan. Penggunaan perangkat komputer dalam proses pembelajaran diharapkan dapat membuat siswa lebih tertarik dengan materi ajar ang disajikan karena divisualisasikan dengan baik dan lebih interaktif. 


\begin{abstract}
Alasan peneliti memilih pengembangan perangkat pembelajaran IPS digital berbasis Problem Based Learning Karena dari hasil pengamatan sementara peneliti, perangkat pembelajaran yang digunakan oleh guru IPS di SMP Negeri 10 Mataram saat ini masih belum efektif dan praktis. Perangkat pembelajaran yang digunakan cenderung bersifat teacher oriented, padahal semestinya dalam pembelajaran kurikulum 2013, pembelajaran yang terjadi dikelas harus bersifat student centris dan masih belum berorientasi pada keterampilan memecahkan masalah dan berpikir kritis peserta didik.

Dari hasil pengamatan sementara dan wawancara peneliti dengan guru IPS di SMP Negeri 10 Mataram diperoleh hasil: (1) RPP yang disusun oleh guru belum secara eksplisit menunjukan proses pembelajaran yang berorientasi pada aplikatif, mengembangkan kemampuan berpikir kritis, kemampuan belajar, rasa ingin tahu dan sikap peduli dan bertnggung jawab terhadap lingkungan alam dan sosial. (2) bahan ajar yang digunakan hanya terbatas pada buku siswa sebagai satusatunya sumber belajar, dan LKS yang digunakan masih bersifat umum, yang hanya menggali aspek kognitif peserta didik. Akibatnya proses pembelajaran cenderung didominasi oleh guru, suasana pembelajaran kurang menyenangkan dan materi yang diberikan belum berkaitan dengan masalah kehidupan sehari-hari. Oleh Karena itu pengembangan perangkat pembelajaran yang meliputi RPP, bahan ajar dan LKS perlu dilakukan agar proses pembelajaran dapat berjalan lebih baik.
\end{abstract}

\section{METODE}

Penelitian ini merupakan penelitian research and development $(\mathrm{R} \& \mathrm{D})$ atau penelitian pengembangan. Metode penelitian ini digunakan untuk menghasilkan produk tertentu dan menguji keefektifan produk tersebut (Sugiyono, 2010: 407). Produk yang dihasilkan dari penelitan ini meliputi: Silabus, Rencana Pelaksanaan Pembelajaran (RPP), Lembar Kerja Siswa (LKS), Buku Ajar Siswa (BAS), lembar penilaian untuk mengukur kemampuan berpikir kritis siswa dan media pembelajaran berbasis digital.

$$
\text { Pengembangan perangkat }
$$
pembelajaran dengan model Problem Based Learning yang digunakan dalam penelitian ini mengikuti langkah-langkah model pengembangan perangkat Thiagarajan,
Semmel dan Semmel (1974) yaitu model 4D (four D model) yang terdiri dari define, design, develop and disseminate. Model ini diadaptasi menjadi model 4-P yaitu Pendefinisian, Perencanaan, Pengembangan dan Penyebaran. Pengembangan perangkat yang digunakan dimodifikasi sesuai dengan kebutuhan penelitian di lapangan, oleh karena itu, untuk keperluan guru sendiri, maka tahapan keempat yaitu penyebaran belum dilakukan.

Subyek dalam penelitian ini adalah perangkat pembelajaran model Problem Based Learning materi fungsi dan peran sumber daya alam dalam pembangunan nasional, yang di uji cobakan pada siswa SMP Negeri 10 Mataram kelas VIII semester genap tahun ajaran 2016-2017.

Teknik analisis data yang digunakan dalam penelitian ini yaitu teknik analisis validitas perangkat pembelajaran. Kelayakan perangkat pembelajaran dianalisis berdasarkan data yang diperoleh dari hasil validasi perangkat pembelajaran, meliputi silabus, RPP, BAS, LKS, Tes pengetahuan, Tes kemampuan berpikir kritis dan Media. Analisis keefektifan perangkat menggunakan analisis keterlaksanaan pembelajaran, analisis hasil belajar, analisis respon siswa dan analisis kendala pembelajaran.

\section{HASIL DAN PEMBAHASAN}

Berdasarkan hasil analisis validitas perangkat yang dikembangkan meliputi validitas silabus, Rencana Pelaksanaan Pembelajaran (RPP), Bahan Ajar Siswa (BAS), Lembar Kerja Siswa (LKS), instrumen penilaian pengetahuan dan berpikir kritis, serta media macromedia flash. Perangkat pembelajaran yang dikembangkan berdasarkan hasil validasi dinyatakan sangat valid dan layak digunakan dalam kegiatan pembelajaran.

Analisis keefektifan perangkat pembelajaran diilhat dari keterlaksanaan RPP yang di ujicobakan didapatkan hasil bahwa RPP yang dikembangkan pada saat uij coba di SMP N 10 mataram secara umum terlaksana sangat baik.

Keefektifan perangkat pembelajaran dinilai dari hasil tes aspek pengetahuan siswa pada materi peran dan fungsi sumber daya alam pesisir ampenan dalam pembangunan nasional dengan predikat minimal B atau ketuntasan minimal 75 (Permendiknas No 53 Tahun 2015: 43). Berdasarkan hasil pre-test aspek pengetahuan, semua siswa belum mencapai 
ketuntasan belajar individual dan hanya mencapai nilai rata-rata 32 dengan predikat D. sedangkan nilai post-test aspek pengetahuan yang dilakukan di akhir kegiatan pembelajaran dengan menggunakan model Problem Based Learning, terdapat peningkatan nilai siswa menjadi rata-rata 78,5 dengan predikat $\mathrm{B}$. kategori ketuntasan klasikal sebesar 91\%, terbukti dengan jumlah siswa yang tuntas belajar sejumlah 30 siswa, sedangkan siswa yang tidak tuntas hanya sejumlah 3 siswa.

Berdasarkan data tersebut, dapat diketahui pula bahwa pembelajaran dengan model Problem Based Learning dapat meningkatan aspek pengetahuan siswa. Hal ini terbukti dengan nilai rata-rata $\mathrm{N}$-gain sebesar 0,68 dalam kategori sedang (Hake, 1991: 1). Dari sejumlah 33 siswa kelas VIII $\mathrm{J}$, terdapat 11 siswa yang mengalami peningkatan nilai post test dengan kategori tinggi. Hal ini karena selama proses pembelajaran, berdasarkan hasil observasi siswa tersebut merupakan siswa yang bersungguh-sungguh dalam mengikuti kegiatan pembelajaran. Kemampuan aspek pengetahuan siswa dapat berkembang beriringan dengan kemampuan berpikir kritis siswa.

Keefektifan perangkat pembelajaran dinilai dari hasil tes keterampilan berpikir kritis siswa pada materi peran dan fungsi sumber daya alam pesisir ampenan dalam pembangunan ekonomi dengan predikat minimal B atau skor ketuntasan minimal 75 (Permendikbud No 53 Tahun 2015: 43). Berdasarkan hasil pre-test keterampilan berpikir kritis, semua siswa belum mencapai ketuntasan belajar individual dan hanya memperoleh skor rata-rata 39 dengan predikat D atau kurang. Sedangkan nilai post-test siswa mencapai skor rata-rata sebesar 76 dengan predikat B atau Baik. Jumlah siswa yang mencapai kriteria ketuntasan individual sebanyak 27 siswa, sedangkan ketuntasan klasikal yang dicapai sebanyak $82 \%$.

Berdasarkan data tersebut, dapat diketahui pula bahwa kegiatan pembelajaran dengan model Problem Based Learning dapat meningkatkan kemampuan berpikir kritis siswa. Hal ini ditunjukkan dengan nilai rata-rata $\mathrm{N}$-gain sebesar 0,62 dengan kriteria sedang (Hake, 1999: 1). Dari 33 siswa di kelas VIII J, terdapat 5 orang siswa yang mengalami peningkatan nilai post test dan termasuk dalam kategori tinggi. Hal ini terjadi karena selama proses pembelajaran siswa tersebut mengikutinya dengan bersungguh-sungguh. Tetapi hanya terdapat 3 orang siswa yang mengalami peningkatan nilai post test pada aspek pengetahuan dan aspek berpikir kritis secara bersamaan pada kategori tinggi.

Kemampuan berpikir kritis siswa dapat berkembang dengan baik jika guru terlebih dahulu mampu menciptakan suasana belajar yang nyaman sehingga memungkinkan siswa untuk saling berinteraksi dan berdiskusi (Filsaime, 2008: 92-93). Hasil temuan dalam penelitian ini sesuai dengan hasil temuan pada penelitian yang pernah dilakukan oleh Rahayu (2015) yang menyatakan bahwa dengan penggunaan perangkat pembelajaran berbasis Problem Based Learning dapat meningkatkan kemampuan siswa dalam memecahkan masalah. Zivkoviu (2016) juga menyatakan bahwa pembelajaran dengan model berpikir kritis, terdapat peningkatan keterlibatan siswa secara aktif dalam dialog, diskusi, menulis dan memecahkan masalah serta dapat berpikir dalam tahapan yang lebih tinggi dan mampu mengevaluasi kegiatan pembelajaran.

Level atau tingkatan keterampilan berpikir kritis siswa mengalami peningkatan. Sebelum pembelajaran dengan model Problem Based Learning, jumlah siswa dengan keterampilan berpikir kritis pada level sangat kurang terampil sejumlah 4 siswa atau sekitar $12 \%$ dan siswa dengan level berpikir kritis kurang terampil sejumlah 29 siswa atau sekitar $88 \%$. Sedangkan setelah penerapan pembelajaran dengan model Problem Based Learning, siswa mengalami peningkatan kemampuan berpikir kritisnya. Terdapat 1 siswa atau sekitar 3\% dengan level berpikir kritis sangat terampil, 8 siswa atau sekitar $24 \%$ dengan level berpikir kritis cukup terampil dan 24 siswa atau sekitar $73 \%$ dengan level berpikir kritis terampil. Peningkatan tersebut menunjukkan bahwa penerapan pembelajaran model Problem Based Learning dengan media digital macromedia flash pada materi peran dan fungsi sumber daya pesisir ampenan dapat meningkatan kemampuan berpikir kritis siswa.

Butir soal berpikir kritis yang diberikan, dinyatakan sensitif apabila memiliki sensitivitas $\geq 0,3$ yang berarti bahwa butir soal tersebut peka terhadap efek-efek pembelajaran sehingga dapat dikatakan bahwa tes tersebut dapat digunakan sebagai instrumen untuk mengukur keterampilan berpikir kritis siswa (Gronlund, 1982: 105). Butir soal yang diberikan digunakan untuk mengukur pengaruh pembelajaran berbasis Problem Based Learning terhadap keterampilan 
berpikir kritis siswa pada materi peran dan fungsi sumber daya pesisir ampenan dalam pembangunan ekonomi.

Indikator soal berpikir kritis siswa yang memiliki sensitivitas paling tinggi adalah indikator menentukan tindakan atau solusi alternatif sebesar 0,42. Sedangkan indikator soal yang memiliki sensitivitas paling rendah yaitu pada indikator memberikan penjelasan sederhana dan mengkonstruksi argumen dengan nilai sensitivitas masing-masing 0,36. Beberapa faktor yang menyebabkan hal itu terjadi adalah tidak semua siswa kelas VIII J mampu mengkomunikasikan penjelasan sederhana terhadap suatu masalah dengan bahasa yang jelas. Siswa cenderung memberikan jawaban atau pendapat yang padat dan jelas, tanpa disertai dengan alasan. Oleh karena itu, pembelajaran berbasis Problem Based Learning perlu dilatihkan pada materi pelajaran IPS yang lain sehingga kemampuan berpikir kritis siswa dapat lebih berkembang. Kompetensi berupa kemampuan berkomunikasi dengan memberikan alasan yang logis merupakan salah satu indikator berpikir kritis yang perlu dikembangkan agar siswa dapat bersaing di era global.

Keefektifan perangkat pembelajaran juga dinilai dari respon siswa terhadap komponen-komponen kegiatan pembelajaran dengan menggunakan model Problem Based Learning yang dikumpulkan dengan menggunakan angket respon siswa. Persentase skor respon siswa dikatakan baik jika memiliki interval 61100\% (Riduwan, 2012: 15). Hasil analisis respon siswa akan digunakan sebagai bahan pengambilan keputusan yang lebih baik tentang pengorganisasian pembelajaran.

Berdasarkan hasil analisi dapat dinyatakan bahwa siswa memberikan respon positif terhadap perangkat pembelajaran maupun kegiatan pembelajaran dengan model Problem Based Learning yang diajarkan selama tiga kali pertemuan. Seluruh siswa memberikan respon positif dan sangat tertarik pada topik yang dipelajari, tampilan Lembar kerja Siswa (LKS), model dan metode pembelajaran yang diujicobakan, serta cara guru mengajar dengan menggunakan model Problem Based Learning untuk meningkatkan kemampuan berpikir kritis siswa. Sedangkan ketertarikan siswa terhadap Bahan Ajar Siswa (BAS) yang digunakan dalam pembelajaran hanya sejumlah $85 \%$, sebanyak $15 \%$ siswa tidak tertarik dengan Bahan Ajar Siswa (BAS) yang digunakan karena beranggapan terlalu banyak materi didalamnya. Sedangkan pada aspek suasana belajar yang dilatihkan guru, sebanyak $12 \%$ siswa menyatakan tidak tertarik dengan alasan sudah pernah diajar menggunakan model Problem Based Learning pada jenjang sekolah sebelumnya, ataupun pada saat dilakukan ujicoba kurikulum 2013. Pada aspek media pembelajaran yang digunakan, sebanyak $12 \%$ siswa menyatakan tidak tertarik dengan tampilan media karena tidak bisa mencoba langsung pada saat dilakukan ujicoba di sekolah.

Berdasarkan hasil analisis respon siswa pada aspek keterbaruan pembelajaran dengan menggunakan perangkat model pembelajaran Problem Based Learning yang dikembangkan, diperoleh bahwa siswa memberikan respon positif terhadap topik yang dipelajari, model dan metode pembelajaran yang digunakan serta cara guru mengajar. Dari sisi Bahan Ajar Siswa (BAS) dan LKS yang digunakan dalam pembelajaran hanya terdapat $94 \%$ siswa dan $91 \%$ siswa yang merasa sangat baru, sisanya sekitar $6 \%$ menyatakan BAS yang digunakan tidak baru dan 9\% siswa menyatakan LKS yang digunakan tidak baru untuk mereka, hal itu terjadi karena siswa pernah diikutsertakan dalam program ujicoba pembelajaran dengan kurikulum 2013 pada tingkatan kelas sebelumnya. Terdapat $6 \%$ siswa atau sejumlah 2 orang siswa yang menyatakan bahwa Bahasa dalam BAS dan LKS sulit dimengerti dan sejumlah 3 orang siswa atau sekitar 9\% menyatakan tidak tertarik dengan BAS dan LKS yang digunakan dalam pembelajaran berbasis Problem Based Learning. Sebanyak $100 \%$ siswa menyatakan ketertarikannya terhadap kegiatan dalam BAS dan LKS yang digunakan selama pembelajaran dan beranggapan soal-soal yang terdapat dalam LKS memberikan kebebasan untuk berpendapat.

Dilihat dari sisi keterbaruan siswa terhadap pembelajaran berbasis Problem Based Learning, sebanyak 2 siswa atau sekitar 6\% merasa tidak baru dengan model pembelajaran berbasis Problem Based Learning pada fase mengorientasikan masalah dan melakukan investigasi, pada tahap mengumpulkan dan menganalisis data dan mengevaluasi proses pemecahan masalah terdapat 3 siswa atau sekitar $9 \%$ yang tidak merasa baru terhadap model pembelajaran yang diujicobakan. Sedangkan pada fase mengembangkan hasil karya sejumlah $100 \%$ siswa merasa baru dengan model pembelajaran berbasis Problem Based Learning. 
Respon siswa terhadap penjelasan guru terhadap materi yang dipelajari pada saat dilatihkan dengan menggunakan model pembelajaran berbasis Problem Based Learning sebanyak 3 siswa atau sekitar 9\% merasa tidak jelas dan $100 \%$ siswa merasa bimbingan guru pada saat mengumpulkan informasi dan mengerjakan LKS sudah jelas. Ketidak jelasan siswa terhadap penjelasan guru terhadap materi yang disampaikan karena siswa kurang fokus pada saat kegiatan pembelajaran berlangsung. Dari aspek minat siswa terhadap pembelajaran dengan model Problem Based Learning, seluruh siswa menyatakan berminat dan tertarik jika model pembelajaran Problem Based Learning digunakan pada materi atau topik bahasan yang lain. hal ini karena pada saat pembelajaran dengan model Problem Based Learning, siswa diberikan kebebasan untuk berpendapat dan suasana belajar yang tercipta sangat menarik untuk siswa.

Hasil respon siswa terhadap alat penilaian berupa aspek pengetahuan, sebagian besar siswa menganggap mudah. Hal ini karena semua materi yang digunakan dalam kegiatan pembelajaran sudah terdapat pada Bahan Ajar Siswa (BAS) sebagai salah satu sumber belajar yang digunakan dalam kegiatan pembelajaran. Sedangkan untuk aspek keterampilan berpikir kritis, sebanyak $24 \%$ siswa menganggap sulit. Hal ini disebabkan karena siswa merasa tes berpikir kritis merupakan sesuatu hal yang baru, selain itu siswa masih belum mampu untuk mengkomunikasikan hasil penyelidikan dengan efektif. Selama proses pembelajaran berlangsung, guru memberikan bimbingan terhadap siswa ataupun kelompok yang kesulitan dalam mengikuti tahapan proses pembelajaran berbasis Problem Based Learning .

Berdasarkan hasil dan pembahasan penelitian, dapat dinyatakan bahwa pengembangan perangkat pembelajaran dengan model Problem Based Learning layak (valid dan efektif) untuk digunakan dalam meningkatkan keterampilan berpikir kritis siswa.

Dalam penerapan pembelajaran dengan model Problem Based Learning yang telah dilakukan terdapat beberapa kendala atau hambatan dalam pembelajaran. Kendala-kendala tersebut disajikan pada Tabel 4. 27. Kendala pertama yang dihadapi pada pertemuan kesatu, siswa ribut dan tidak kondusif saat pembagian kelompok. Hal tersebut dapat diatasi dengan perlunya ketegasan guru dalam memanajemen waktu pada saat pembagian kelompok, guru perlu membagi kelompok secara heterogen, sehingga siswa tidak cenderung memilih berkelompok dengan teman-teman akrabnya saja. Hambatan kedua yang muncul dalam penerapan pembelajaran dengan model Problem Based Learning yaitu siswa kurang aktif dan antusias dalam membaca Bahan Ajar Siswa (BAS) yang dibagikan oleh guru. Hal ini dapat diatasi dengan guru harus mengingatkan siswa untuk menbaca materi yang akan dipelajari sebelum kegiatan pembelajaran dimulai.

Kendala ketiga yang muncul dalam penerapan pembelajaran dengan model Problem Based Learning yaitu manajemen waktu yang kurang tepat pada pertemuan petama dan kedua. Waktu menjadi kendala yang dominan dalam penerapan pembelajaran Problem Based Learning karena selama ini siswa belum terbiasa dengan model pembelajaran Problem Based Learning yang disertai dengan tahapan yang membutuhkan kemandirian siswa dalam memecahkan masalah. Solusi yang dapat dilakukan untuk mengatasi kendala waktu yaitu dengan memperketat pengaturan waktu dan menginformasikan pada siswa waktu yang tersedia untuk setiap tahapan Problem Based Learning.

\section{PENUTUP}

\section{Simpulan}

Berdasarkan hasil analisis penelitian, maka diperoleh kesimpulan sebagai berikut: 1. Validitas perangkat pembelajaran yang dikembangkan meliputi validitas silabus, Rencana Pelaksanaan Pembelajaran (RPP), Bahan Ajar Siswa (BAS), Lembar Kerja Siswa (LKS), instrumen penilaian pengetahuan dan berpikir kritis, serta media macromedia flash. Perangkat pembelajaran yang dikembangkan berdasarkan ahsil validasi dinyatakan sangat valid dan layak digunakan dalam kegiatan pembelajaran.

2. Keefektifan perangkat pembelajaran dilihat dari keterlaksanaan Rencana Pelaksanaan pembelajaran (RPP) selama tiga kali pertemuan termasuk dalam kategori sangat baik. Hal ini karena secara keseluruhan tahapan dalam proses pembelajaran terpenuhi. Kendala yang dihadapi selama proses pembelajaran dengan model Problem Based Learning yang terdapat pada petemuan pertama dapat diatasi oleh guru pada pertemuan kedua dan ketiga. Sehingga pada 
pertemuan ketiga proses pembelajaran dapat berjalan lancar. Peningkatan kemampuan keterampilan berpikir kritis siswa termasuk dalam kategori sedang. Nilai peningkatan (N-gain) yang diperoleh sebesar 0,62 dengan kategori sedang. Siswa menunjukkan respon yang positif selama kegiatan pembelajaran dengan model Problem Based Learning.

\section{Saran}

Berdasarkan kesimpulan yang telah dipaparkan, maka peneliti memberikan saran-saran sebagai berikut:

1. Pembelajaran dengan menggunakan model Problem Based Learning perlu diterapkan pada materi pelajaran yang lain dengan menggunakan media yang bervariasi yang disesuaikan dengan karakteristik siswa. Hal ini karena siswa terlihat antusias dan memberikan respon positif selama pembelajaran dengan model Problem Based Learning.

2. Perlu adanya penelitian lain yang sejenis pada mata pelajaran yang lain, hal ini untuk memperkuat kesimpulan penelitian pengembangan perangkat pembelajaran pada tema peran dan fungsi sumber daya pesisir ampenan dalam pembangunan ekonomi.

\section{DAFTAR PUSTAKA}

Arends, Richard I. (2008). Belajar untuk mengajar. Yogyakarta: Pustaka pelajar.

Borich, G.D. (1994). Observation Skill for Effective Teaching. United States of America: Macmillan Publishing Company.

Ciftci, Sabahattin. (2015). The effect of using problem based learning in social studies education and student attitude toward social studies courses. Journal Procedia.

Dimyati dan Mudjiono, (2013). Belajar dan Pembelajaran. Jakarta: Rineka Cipta.

Eldy, Folly, Elnetthra, Sulaiman, Fauziah. (2013). The role of PBL in improving physics student creative thinking and its imprint on gender. International Journal of Education and Research. Vol. 1. No. 6. June 2013.

Ennis, R.H. (1996). Critical Thinking. The University of Illinois: Prentice Hall Inc.

Fadhlillah. (2014). Implementasi Kurikulum 2013 dalam Pembelajaran SD/MI,
SMP/MTs, SMA/MA. Yogyakarta: Ar-ruzz Media.

Filsaime, D.K. (2008). Menguak Rahasia Berpikir Kritis dan Kreatif. Jakarta: Prestasi Pustakaraya.

Fisher, A. (2009). Berpikir Kritis Sebuah Pengantar. Jakarta: Erlangga.

Gronlund, N.E. (1982). Constructing Achievement Test. USA: Prentice Hall Inc.

Hakke. (1999). Analyzing change/gain score (online). http: www.physicindiana.edu/sdi. Analyzing change-gain.

Ibrahim, M dan Nur, M. (2000). Pengajaran Berdasarkan Masalah. Surabaya: Unesa University Press

Ibrahim, M dan Wahyusukartiningsih. (2014). Model Pembelajaran Inovatif Melalui Pemaknaan. Surabaya: Unesa University Press

Kardi, S. (2012). Pengantar Pengembangan Kurikulum dan Rencana Pelaksanaan Pembelajaran. Surabaya: Universitas Negeri Surabaya.

Mahboobeh. Haghparast. (2014). Cultivating critical thinking through elearning environmental tools: a review. Procedia

Nasution.(2011). Kajian Pembelajaran IPS di Sekolah. Surabaya: Unesa University Press.

Prastowo, A. (2014). Panduan Kreatif Membuat Bahan Ajar Inovatif Menciptakan Metode Pembelajaran yang Menarik dan Menyenangkan. Yogyakarta: Diva Press.

Plomp, T. dan Nieven, N. (2007). An Intruduction to Educational Design Research. Shanghai: Normal University.

Ratumanan, T.G dan Laurens, T. (2011). Penilaian Hasil Belajar pada Tingkat Satuan Pendidikan edisi 2. Surabaya: Unesa University Press.

Richey, R.C. and Nelson, W. (2009). Development Research: Studies of Instructional Design and Development. Bloomington: The Association for Educational Communications and Technology.

Riduwan. (2012). Skala Pengukuran Variabel-Variabel Penelitian. Bandung: Alfabeta.

Sanjaya, W. (2006). Strategi Pembelajaran Berorientasi Standar Proses Pendidikan. Jakarta: Prenada Media Group.

Sugiyono. (2010). Metode Penelitian Kuantitatif, Kualitatif \& RnD. Bandung: Alfabeta. 
Pengembangan perangkat pembelajaran digital berbasis PBL untuk meningkatkan kemampuan berpikir kritis siswa tema peran dan fungsi sumber daya alam

Suprijono, Agus. (2009). Cooperative

Learning (Teori dan Aplikasi PAIKEM), Yogyakarta: Pustaka Pelajar.

Woolfolk, A. (2009). Educational Psychology Active Learning Edisi Kesepuluh Bagian Kedua. Penerjemah 